\title{
СТАН СЛИЗОВОЇ ОБОЛОНКИ ШЛУНКА ЗА ДАНИМИ ЕНДОСКОПІЇ ІЗ ВИСОКОЮ РОЗДІЛЬНОЮ ЗДАТНІСТЮ ТА РЕЖИМОМ ВУЗЬКОСМУГОВОЇ ВІЗУАЛІЗАЦІЇ У ХВОРИХ НА АТРОФІЧНИЙ ГАСТРИТ, ПОЄДНАНИЙ 3 ПАТОЛОГІЕЮ ЩИТОПОДІБНОЇ ЗАЛОЗИ
}

\begin{abstract}
Стан слизової оболонки шлунка за даними ендоскопії із високою роздільною здатністю та режимом вузькосмугової візуалізації у хворих на атрофічний гастрит, поєднаний 3 патологією щитоподібної залози
\end{abstract}

Л. М. Мосійчук, О. В. Сімонова, І. С. Коненко, О. П. Петішко

ДУ «Інститут гастроентерології національної академії медичних наук України», м. Дніпро

Резюме. Рак і передракова патологія шлунка представляють на сьогодні важливу проблему в медицині. Особливого значення надають виявленню додаткових фракторів ризику розвитку раку илунка. Результати поодиноких досліджень показали взаємозв'язок між розвитком атрофрічного гастриту й захворюваннями щитоподібної залози.

Мета дослідження - визначити особливості макро- і мікроструктури слизової оболонки шлунка за даними ендоскопічного дослідження з режимами збільшення і вузькосмугової візуалізації у хворих на хронічний атрофрічний гастрит залежно від наявності структурних змін у щитоподібній залозі (ЩЗ).

Матеріали і методи. 45 хворим на атрофрічний гастрит проводили ендоскопічне обстеження шлунка за допомогою ендоскопа з високою роздільною здатністю й вузькоспектральною візуалізацією та ультразвукове дослідження щитоподібної залози, за результатами якого хворих поділили на наступні групи: перша група хворі з наявністю вогнищевих змін у щз, друга - пацієнти з дифузними змінами Щз, група порівняння - без патологічних змін щЗ. Проводили статистичний та кореляційний аналізи отриманих даних.

Результати. Аналіз отриманих даних дозволив виявити збільшення поширеності еритематозних змін в шлунку, тенденцію до збільшення частоти і поширеності вузлувато-бугристого рельєфу в групі хворих із вогнищевими утвореннями у щз, збільшення частоти ерозій, виразок і геморагій у пацієнтів зі структурними змінами в щЗ, суттєве збільшення частоти дифузного поширення кишкової метаплазії (КМ) у шлунку в осіб із вогнищевими змінами в ЩЗ, порівняно з хворими з дифузними змінами структури щз, або без них; дисплазію слизової оболонки шлунка виявлено в середньому тільки у хворих із структурними змінами Щз з тенден(с). М. Мосійчук та ін., 2020
State of gastric mucosa according to high resolution endoscopy with narrow-band imaging in patients with atrophic gastritis combined with thyroid diseases

L. M. Mosiychuk, O. V. Simonova, I. S. Konenko, O. P. Petishko

Institute of Gastroenterology of the National Academy of Medical Sciences of Ukraine, Dnipro

e-mail: lidiya.gastro@gmail.com

Summary. Cancer and precancerous stomach pathology are an important problem in medicine today. It is important to identify additional risk factors for the development of stomach cancer. Single studies have shown the relationship between the development of atrophic gastritis and thyroid diseases.

The aim of the study - to determine the peculiarities of the gastric mucosa structure in patients with chronic atrophic gastritis, depending on the presence of thyroid gland structural changes.

Materials and Methods. 45 patients with atrophic gastritis underwent upper endoscopy using the endoscope with high resolution and narrow-band imaging modes and ultrasound examination of the thyroid gland. According to the ultrasound examination results, the patients were divided into the following groups: I - patients with focal changes, II - patients with diffuse changes of the thyroid gland, the comparison group - patients without changes in the thyroid gland. Statistical and correlation analyzes were carried out.

Results. It was revealed an increase in the prevalence of erythematous changes, a tendency to an increase in the frequency of nodular relief of the gastric mucosa in patients with focal lesions in the thyroid gland, an increase in the frequency of stomach erosions, ulcers and hemorrhages in patients with structural changes in the thyroid gland, a significant increase in the frequency of diffuse spread of gastric mucosa intestinal metaplasia in patients with focal thyroid gland changes, compared with patients with diffuse thyroid gland changes or without them; dysplasia of the gastric mucosa was detected only in patients with structural thyroid gland changes and more often in patients of group I ( $p>$ 0.05). The obtained differences were confirmed by correlation analysis. 
цією до збільшення частоти цієї ознаки у пацієнтів першої групи ( $p>0,05)$. Отримані відмінності підтверджено кореляційним аналізом.

Висновки. У хворих на атрофрічний гастрит, поєднаний із патологією Щз (дифузного й вогнищевого характеру), виявлено суттєве збільшення частоти структурних змін слизової оболонки шлунка, в т. ч. передракового характеру, що підтверджено результатами корелячійного аналізу й свідчить про необхідність подальшого ретельного вивчення даної проблеми.

Ключові слова: передракові зміни слизової оболонки шлунка; ендоскопічне дослідження; атрофрічний гастрит; кишкова метаплазія; щитоподібна залоза.

\section{ВСТУП}

Рак і передракова патологія шлунка представляють на сьогодні важливу проблему в медицині, а своєчасна діагностика цих захворювань є найважливішим завданням.

Згідно з консенсусами MAPS (2012 р.) й MAPS II (2019 р.), до передракових станів шлунка відносяться атрофрія слизової оболонки (СО) шлунка й кишкова метаплазія (KM) [1, 2]. На сьогодення важливе значення надають виявленню додаткових фракторів ризику розвитку раку шлунка, основні 3 яких представлено в Кіотському глобальному консенсусі щодо Helicobacter pylori-асоційованого гастриту (2015), але пошук їх досі триває [3, 4].

Так, ще на початку XX ст. було відмічено взаємозв'язок між розвитком хронічного гастриту, в тому числі атрофрічного, й захворюваннями щитоподібної залози (ЩЗ) $[5,6]$.

Згідно з сучасними уявленнями, щ3 і шлунок мають генетичну спільність та деякі ембріологічно, біохімічно схожі особливості, що зумовлює тісний взаємозв'язок між фрункціональним станом цих органів і визначає єдині патогенетичні механізми фрормування низки захворювань, у т. ч. автоімунних захворювань щз і атрофрічного (аутоімунного) гастриту $[5,6]$.

За даними експериментальних та клінічних досліджень виявлено, що одним із можливих фракторів, що впливає на функціонально-морфологічний стан шлунка, є гормональний стан щЗ. Також з'явились відомості про те, що гормони щз, беручи участь у нейроендокринній регуляції, впливають на стан СО шлунка [6].

Результати окремих експериментальних досліджень свідчать про суттєву частоту взаємно зумовлених розладів щ3 і верхніх відділів травного тракту [7, 8]. У поодиноких роботах відмічено взаємозв'язок між збільшенням розмірів щз (зобом), дефріцитом йоду і розвитком аденокарциноми шлунка [6-8]. Праць, які стосуються взаємозв'язку між атрофрічним гастритом (АГ) і хворобами щЗ, вкрай мало, значна кількість із них застарілі. Тобто питання потребує подальшого вивчення.
Conclusions. In patients with atrophic gastritis combined with thyroid pathology (diffuse and focal), a significant increase of the gastric mucosa structural changes, including precancerous ones, was revealed, which is confirmed by the results of a correlation analysis.

Key words: precancerous changes of the stomach mucosa; endoscopic examination; atrophic gastritis; intestinal metaplasia; thyroid gland.

На сьогодні основним методом діагностики передракових станів/змін і раку шлунка $є$ ендоскопія [1-3, 9]. За даними дослідників, загальноприйнята ендоскопія в цілому світі не дозволяє надійно діагностувати, тобто точно диференціювати і діагностувати передпухлинні стани шлунка (гелікобактерний гастрит, атрофрію СО або КМ тощо). Застосування ендоскопів із високою роздільною здатністю (High resolution endoscopy), з режимами збільшення й вузькосмугової візуалізації («Narrow band imaging» - NBI) перевершує стандартну ендоскопію і дає можливість під час ендоскопічного дослідження вивчати мікроструктуру СО, виявляти дрібні вогнища КМ, дисплазії, атипії епітелію, які слабо візуалізуються при застосуванні звичайного освітлення, отримувати надточну, таргентну біопсію [1, 9-16].

Метою дослідження було визначити особливості макро- і мікроструктури слизової оболонки шлунка за даними ендоскопічного дослідження з режимами збільшення і вузькосмугової візуалізації у хворих на хронічний атрофрічний гастрит залежно від наявності структурних змін у щитоподібній залозі.

\section{МАТЕРІАЛИ I МЕТОДИ}

Обстежено 45 хворих на АГ. Усім обстеженим проводили сонологічне дослідження щЗ на сканеpi Toshiba Xario лінійним трансдюсером частотою 5-12 МГц. Для аналізу структурних характеристик щ3 користувалися В-режимом, кольоровим і енергетичним доплером, 3 урахуанням тиреоїдного об'єму, який розраховували за фрормулою J. Brunn. У 2D-режимі оцінювали стан контурів, капсули, ехогенність структури залози, додаткові утворення, регіонарні лімфратичні вузли.

За результатами ультразвукового дослідження хворих на АГ поділили на групи за характером змін у структурі щ3: перша група - хворі з наявністю вогнищевих змін в щ3 (19 пацієнтів) та друга група - пацієнти з дифузними змінами щз (18 осіб). 8 хворих без патологічних змін ЩЗ склали групу порівняння.
Вісник медичних і біологічних досліджень Bulletin of Medical and Biological Research
3(5),2020 
Макроскопічний стан СО стравоходу, шлунка і дванадцятипалої кишки вивчали за допомогою езофрагогастродуоденоскопії за загальноприйнятою методикою 3 використанням відеоендоскопічної системи EVIS EXERA III 3 гастроскопом Olympus 190 (Японія).

Під час ендоскопічного дослідження спочатку проводили огляд СО в білому світлі без збільшення, потім - у вузькоспектральному режимі (NBI) і в режимі ближнього фрокуса, проводили фротофріксацію. Для підсилення якості зображення в ряді випадків виконували хромоендоскопію за допомогою 0,2 \% розчину індигокарміну. При аналізі даних ендоскопічного дослідження в білому світлі визначали стан просвіту органів, ссрінктерів (нижнього стравохідного, пілоричного), вираження складок, перистальтики, наявність і вираження дуоденогастрального рефлюксу, макроскопічних ознак запалення, атрофії СО. Запалення (гіперемію, набряк) й атрофрію СО шлунка оцінювали за поширеністю (антральний відділ, диоруно).

При застосуванні NBI і ближнього фрокуса оцінювали: мікроструктуру поверхні СО шлунка (характер і регулярність ямкового малюнка) і субепітеліальну будову (малюнок) капілярної сітки [9-16].

Наявність атрофії СO шлунка визначали при появі в білому світлі вогнищ стоншення, западань СО блідного, білуватого кольору, видимих підслизових судин, в режимі NBI - зникнення малюнка капілярної субепітеліальної сітки 3 хаотично розташованими венулами; оцінювали за поширеністю (антральний відділ, дифрузно).

Діагностику кишкової метаплазії здійснювали при виявленні в режимі NBI пласко-піднятих і пласко-заглиблених вогнищ, які в режимі збільшення мали регулярну гребенеподібну або тубуловільозну мікроструктуру, що у більшості випадків супроводжувалось позитивним симптомом LBC - наявність «світло-блакитних гребенів» (чітко видимі блідо-блакитні лінії або звивини, розташовані на поверхні епітелію).

При наявності десормації мікросудинного малюнка, нерегулярної або відсутньої мікроструктури СО шлунка, позитивного симптому «біла тьмяна субстанція» діагностували дисплазію [9-16].

Пілоризацію залоз тіла шлунка діагностували на основі виявлення в режимі збільшення та NBI паличкоподібного малюнка капілярної сітки, який притаманний для антрального відділу шлунка.

Статистичну обробку результатів досліджень здійснювали методами варіаційної статистики, реалізованими стандартним пакетом прикладних програм Statistica 6.1. Порівняння показників виконували за допомогою $X^{2}$-критерію та F-критерію. Статистичну значущість оцінювали на рівні не нижче, ніж 95,0 \% (p<0,05). Кореляційний аналіз вико- нували з розрахунком коефіцієнтів рангової кореляції Спірмена та їх вірогідності.

\section{РЕЗУЛЬТАТИ Й ОБГОВОРЕННЯ}

У цілому при ендоскопічному дослідженні суттєвих змін з боку стравоходу й дванадцятипалої кишки виявлено не було.

При ендоскопічному обстеженні шлунка у 19 із 45 (42,2 \%) хворих на АГ зафріксовано дуоденогастральний рефлюкс, частота якого була не суттєво вищою у хворих першої групи - 47,4 \% (табл.).

Зміни забарвлення СО шлунка (різний ступінь вогнищевої гіперемії) виявлено у всіх пацієнтів; в більшості вони були поширені в шлунку дифузно $(84,4 \%)$, що свідчить про те, що атрофрічні зміни $\mathrm{CO}$, як правило, сполучаються із запаленням різного ступеня вираження. При порівнянні поширеності еритеми в шлунку в дослідних групах виявлено, що частота дифузної еритеми була суттєво вищою в першій групі й спостерігалась у 100,0 \% випадків, що в 1,6 раза частіше порівняно з групою порівняння $(F=0,019 ; p<0,05)$ та в 1,3 раза порівняно 3 другою групою $\left(X^{2}=4,73 ; p<0,05\right)$.

Ендоскопічні ознаки атрофрії СО шлунка (рис. 1) було виявлено майже у всіх пацієнтів (97,8 \%), при цьому частота атрофії, що обмежена тільки антральним відділом, і частота дисрузних атрофрічних змін СО шлунка були практично однаковими (53,3 і 44,4 \% відповідно). При порівняльному аналізі у групах було виявлено, що частота дифузних атрофрічних змін СО шлунка, за даними ендоскопії, суттєво не відрізнялась.

В обстежених хворих було виявлено різноманітні зміни рельєфу СО: вузлуватість, бугристість, вогнищеві гіперплазії. Вузлувато-бугристий рельєф СО, виявлений у значної кількості випадків (73,3\%), характеризувався наявністю невеликих випинань (протрузій) різного розміру, одиничних і множинних, що іноді створювало рельєф «бруківки», і зазвичай було проявом вогнищевої гіперплазії СО, що при сполученні з атрофрією СО шлунка морфологічно відповідало атрофрічно-гіперпластичному гастриту (рис. 2), ці зміни поширювались переважно дифузно - 24 з 45 (53,3 \%) випадків. Частота і поширеність вузлувато-бугристого рельєфру в цілому мали тенденцію до збільшення у хворих із вогнищевими змінами в щ3. Якщо вказані зміни рельєфу із залученням тільки антрального відділу переважали в групі порівняння, то залучення тільки тіла шлунка відмічено у хворих із наявністю структурних змін щЗ. Водночас диоруне ураження в 1,7 раза частіше мало місце в першій групі пацієнтів відносно групи порівняння.

У 13 із 45 (26,7\%) пацієнтів мали місце вогнищеві гіперплазії різних розмірів, які є ознакою атрофрічно-гіперпластичного гастриту, наявність якого свідчить про досить виражені структурні зміни 
Таблиця. Макроскопічні зміни слизової оболонки шлунка хворих дослідних груп

\begin{tabular}{|c|c|c|c|c|c|c|}
\hline \multirow{2}{*}{ Ендоскопічна ознака } & \multicolumn{2}{|c|}{$\begin{array}{c}\text { Перша група } \\
(n=19)\end{array}$} & \multicolumn{2}{|c|}{$\begin{array}{c}\text { Друга група } \\
(\mathrm{n}=18)\end{array}$} & \multicolumn{2}{|c|}{$\begin{array}{c}\text { Група порівняння } \\
(\mathrm{n}=8)\end{array}$} \\
\hline & $\mathrm{n}$ & $\%$ & $\mathrm{n}$ & $\%$ & $\mathrm{n}$ & $\%$ \\
\hline Дуоденогастральний ресрлюкс & 9 & 47,4 & 7 & 38,9 & 3 & 37,5 \\
\hline Гіпертрофрія складок шлунка & 0 & 0 & 1 & 5,6 & 0 & 0 \\
\hline Згладження складок шлунка & 1 & 5,2 & 2 & 11,1 & 2 & 25,0 \\
\hline Еритема СО шлунка (усього) & 19 & 100,0 & 18 & 100,0 & 8 & 100,0 \\
\hline Антральна еритема СО шлунка & 0 & 0 & 4 & $22,2^{\star}$ & 3 & 37,5 \\
\hline Дифузна еритема СО шлунка & 19 & $100,0^{\#}$ & 14 & $77,8^{*}$ & 5 & 62,5 \\
\hline Атрофрія СО шлунка (усього) & 19 & 100,0 & 17 & 94,4 & 8 & 100,0 \\
\hline Антральна атрофія СО шлунка & 9 & 47,4 & 11 & 61,1 & 4 & 50,0 \\
\hline Дифрузна атрофія СО шлунка & 10 & 52,6 & 6 & 33,3 & 4 & 50,0 \\
\hline Вузлуватий рельєф (усього) & 16 & 84,2 & 12 & 66,7 & 5 & 62,5 \\
\hline Вузлуватий рельєф в антральному відділі шлунка & 1 & 5,2 & 1 & 5,6 & 2 & 25,0 \\
\hline Вузлуватий рельєф в тілі шлунка & 3 & 15,8 & 2 & 11,1 & 0 & 0 \\
\hline Дифрузно-вузлуватий рельєф & 12 & 63,2 & 9 & 50,0 & 3 & 37,5 \\
\hline Геморагії СО шлунка & 5 & 26,3 & 6 & 33,3 & 0 & 0 \\
\hline Ерозії СО шлунка (усього) & 6 & 31,6 & 1 & 5,6 & 0 & 0 \\
\hline Поліпи шлунка & 3 & 15,8 & 0 & 0 & 0 & 0 \\
\hline Гіперплазії шлунка & 5 & 26,3 & 7 & 38,9 & 1 & 12,5 \\
\hline Ксантоми шлунка & 8 & 42,1 & 7 & 38,9 & 3 & 37,5 \\
\hline Виразка шлунка & 1 & 5,3 & 2 & 11,1 & 0 & 0 \\
\hline Пілорична метаплазія тіла шлунка & 8 & 42,1 & 7 & 38,9 & 3 & 37,5 \\
\hline Кишкова метаплазія (усього) & 19 & $100,0^{\#}$ & 16 & 88,9 & 6 & 75,0 \\
\hline Кишкова метаплазія тільки антрального відділу шлунка & 2 & 10,5 & 5 & 27,8 & 3 & 37,5 \\
\hline Кишкова метаплазія тільки тіла шлунка & 1 & 5,2 & 1 & 5,6 & 0 & 0 \\
\hline Дифузна кишкова метаплазія & 16 & $84,2^{\#}$ & 10 & 55,6 & 3 & 37,5 \\
\hline Дисплазія СО шлунка & 3 & 15,8 & 1 & 5,6 & 0 & 0 \\
\hline
\end{tabular}

Примітки: 1) * - р<0,05, достовірна різниця показників першої і другої груп;

2) \# $-p<0,05$, достовірна різниця показників порівняно з групою порівняння.
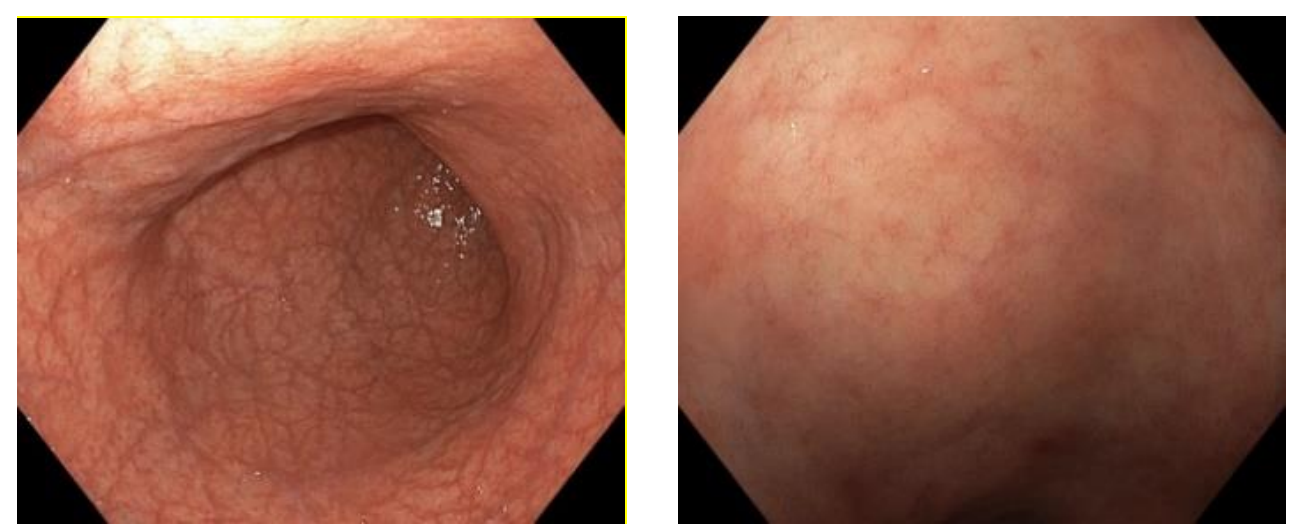

Рис. 1. Хворий С. Ендоскопія в білому кольорі: виражена атрофрія слизової тіла шлунка.

передракової спрямованості. Частота цієї ознаки була у 3 та 2 рази вищою в другій і першій групах хворих відносно групи порівняння (р>0,05).

Тільки у 15,8 \% осіб першої групи виявлено поліпи шлунка, переважно аденоматозні.

Майже у чверті випадків зафріксовано наявність дрібних геморагій СО, які спостерігались тільки у пацієнтів зі структурними змінами в щз без суттєвої різниці між групами.
Гострі ерозії антрального відділу шлунка, в цілому діагностовані в 7345 (15,6 \%) випадків, також спостерігались тільки у хворих зі структурними змінами в щ3, при цьому максимальна частота ерозій була в першій групі (31,6 \%, p>0,05).

У 3 пацієнтів першої та другої груп діагностовано активні виразки антрального відділу шлунка.

Ксантоми шлунка, які є маркером, перш за все атрофічних змін СО шлунка, були зафріксовані у 18 


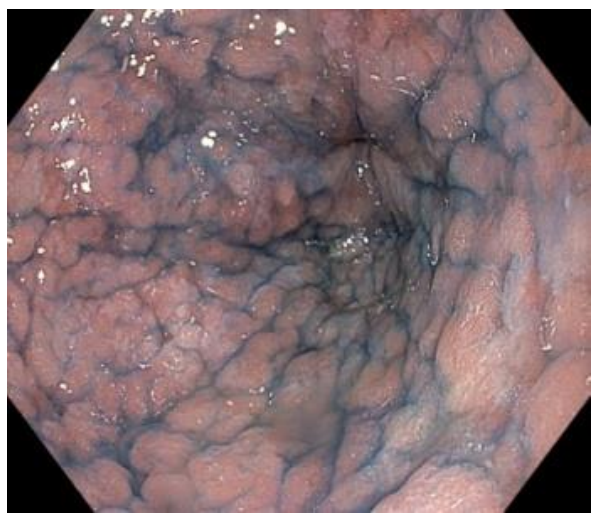

a

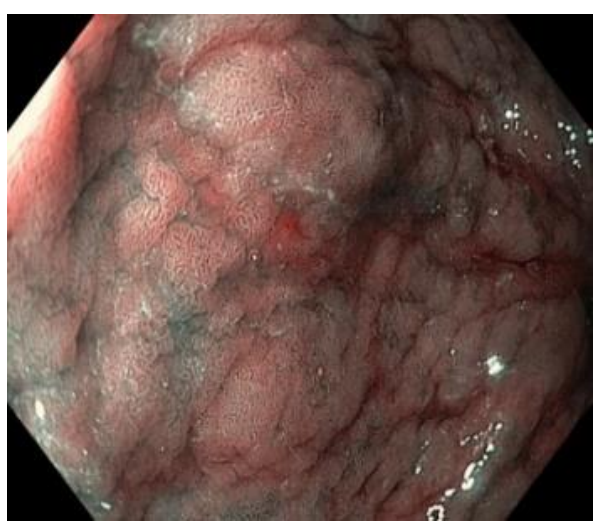

6

Рис. 2. Хвора П. Вузлувато-бугристий рельєф тіла шлунка. Ендоскопія в білому світлі, хромоскопія з розчином індигокарміну (а), ендоскопія у вузькосмуговому режимі (б).

345 (40,0 \%) обстежених хворих. У більшості випадків ксантоми мали пласку форму. Частота їх у групах практично не відрізнялась.

При аналізі даних ендоскопічного дослідження СО шлунка в режимах збільшення і вузькосмугової візуалізації пілорична метаплазія СО тіла шлунка була діагностована в цілому в 18 з 45 (40,0 \%) випадків, з практично однаковою частотою в усіх групах. Водночас ознаки кишкової метаплазії було виявлено у всіх пацієнтів із вогнищевими змінами в щ3, що в 1,3 раза частіше відносно групи порівняння ( $F=0,079 ; p<0,05)$. Вивчення поширеності КМ в шлунку виявило цікаву закономірність, а саме суттєве збільшення частоти дифузного поширення КМ у шлунку в пацієтів першої групи - 84,2 \%, що в 1,5 раза вище порівняно 3 хворими другої групи ( $>0,05)$ та в 2,2 раза відносно групи порівняння $(F=0,027 ; p<0,05)$.

Дисплазію СО шлунка виявлено в 4345 (8,9 \%) випадків тільки у хворих першої та другої груп із трикратним переважанням частоти цієї ознаки у пацієнтів з вогнищевими змінами в щ3 (15,8\%).

Проведений кореляційний аналіз дозволив виявити низку взаємозв'язків між наявністю передракових змін в СО шлунка та структурними змінами щ3 (рис. 3), а саме - частота КМ тіла й антрального відділів шлунка корелювала зі шкалою змін у щ3 - TI RADS, що свідчить про наявність взаємозв'язку між розвитком структурних змін, особливо вогнищевих, у щЗ із розвитком

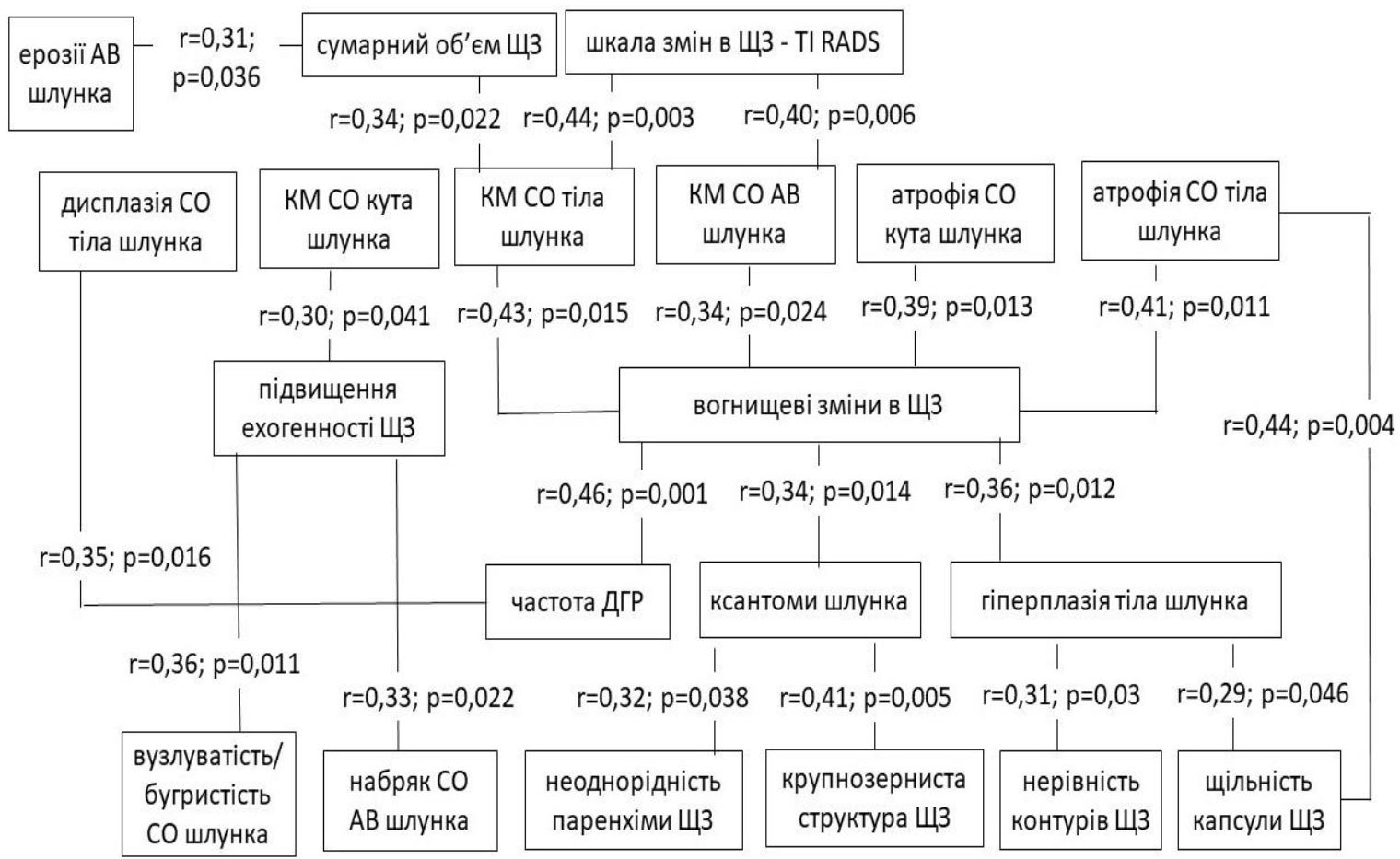

Рис. 3. Кореляційні взаємозв'язки між структурними змінами слизової оболонки шлунка та щитоподібної залози у хворих на атрофрічний гастрит. 
передракових станів у СО шлунка. Крім того, частота ДГР супроводжувалась збільшенням частоти дисплазії СО шлунка за даними ендоскопії зі збільшенням та наявністю вогнищ в щ3. Збільшення сумарного об'єму щЗ корелювало зі змінами рельєору СО шлунка (вузлуватість/бугристість), наявністю кишкової метаплазії СО тіла шлунка та частотою ерозій антрального відділу шлунка.

Нерівність контурів Щ3 прямо корелювала 3 наявністю вогнищевих гіперплазій СО шлунка, що характерно для атрофрічно-гіперпластичного гастриту, наявність якого свідчить про виражені структурні зміни СО шлунка передракової спрямованості.

Збільшення щільності капсули щ3, що спостерігається при тривалому перебігу тиреоїдного процесу, корелювало зі збільшенням частоти вогнищевих гіперплазій СО шлунка і вираженням атрофії СО тіла шлунка. Встановлено також пряму кореляцію між змінами структури щЗ у вигляді неоднорідності паренхіми і наявністю ксантом СО шлунка, що є маркерами передракових станів СО шлунка.

\section{СПИСОК ЛІТЕРАТУРИ}

1. Management of precancerous conditions and lesions in the stomach (MAPS). Guideline from the European Society of Gastrointestinal Endoscopy (ESGE), European Helicobacter Study Group (EHSG), European Society of Pathology (ESP), and the Sociedade Portuguesa de Endoscopia Digestiva (SPED). Guideline / M. Dinis-Ribeiro, M. Areia, A. C. de Vries [et al.] // Endoscopy. - 2012. - Vol. 44 (1). - P. 74-94.

2. Management of epithelial precancerous conditions and lesions in the stomach (MAPS II): European Society of Gastrointestinal Endoscopy (ESGE), European Helicobacter and Microbiota Study Group (EHMSG), European Society of Pathology (ESP), and Sociedade Portuguesa de Endoscopia Digestiva (SPED) guideline update 2019 / P. Pimentel-Nunes, D. Libânio, R. Marcos-Pinto [et al.] // Endoscopy. - 2019. - Vol. 51(4). - P. 365-388.

3. Kyoto global consensus report on Helicobacter pylori gastritis / K. Sugano, J. Tack, E. J. Kuipers [et al.] // Gut. 2015. - No. 64. - P. 1353-1367.

4. Сучасні ендоскопічні критерії стратисрікації хворих на атросрічний гастрит при розвитку передракових змін / Ю. М. Степанов, О. В. Сімонова, Л. М. Мосійчук, О. П. Петішко // Патологія. - 2018. - Т. 15, № 3. - С. 346-353.

5. Autoimmune diseases in autoimmune atrophic gastritis / K. I. Rodriguez-Castro, M. Franceschi, C. Miraglia [et al.] // Acta Biomed. - 2018. - Vol. 89 (8-S). - P. 100-103.

6. Cellini M. Hashimoto's thyroiditis and autoimmune gastritis / M. Cellini, M. G. Santaguida, C. Virili // Front Endocrinol (Lausanne). - 2017. - No 8. - P. 92-102.

7. Kandemir E. G. Gastric carcinoma and thyroid status / E. G. Kandemir, A. Yonem, Y. Narin // Journal of International Medical Research. - 2005. - No. 33. - P. 222-227.

8. Venerito $M$. Autoimmune gastritis in autoimmune thyroid disease / M. Venerito, M. Radunz, K. Reschke // Alimentary Pharmacology and Therapeutics. - 2015. No. 41. - P. 686-693.
Підвищення ехогенності щ3, що є непрямою ознакою хронізації процесу, позитивно корелювало зі змінами рельєфу СО тіла шлунка (вузлуватість/ бугристість), набряком СО антрального відділу та наявністю кишкової метаплазії у зоні кута шлунка. Наявність такої ознаки як крупнозерниста структура щз також позитивно корелювала з ксантомами СО шлунка. Наявність вогнищевих (нодулярних) змін у щз за даними ультразвукової діагностики корелювало з вираженням атрофрії СО тіла й кута шлунка, кишкової метаплазії тіла й антрального відділу (AB), наявністю ксантом та гіперплазій тіла шлунка.

\section{ВИНОВКИ}

У хворих на атрофрічний гастрит, поєднаний із патологією щ3 (дифузного й вогнищевого характеру), виявлено суттєве збільшення частоти структурних змін СО шлунка, в т. ч. передракового характеру, що підтверджено результатами кореляційного аналізу й свідчить про необхідність подальшого ретельного вивчення даної проблеми.

9. Степанов Ю. М. Сучасні ендоскопічні методи діагностики передракових станів шлунка: проблеми і перспективи / Ю. М. Степанов, О.В.Сімонова, Л. М. Мосійчук // Гастроентерологія. - 2017. - № 51(1). - С. 64-72.

10. Коэн Дж. Атлас эндоскопии пищеварительного тракта: возможности высокого разрешения и изображения в узком световом спектре / под. ред. Дж. Коэна ; пер. с англ. под ред. А. А. Будзинского. - М. : Логосфрера, 2012. - 360 c

11. Advanced endoscopic imaging: European Society of Gastrointestinal Endoscopy (ESGE) Technology Review / J. E. East, J. L. Vleugels, P. Roelandt [et al.] // Endoscopy. - 2016. - No. 48. - P. 1029-1045.

12. A multicenter validation of an endoscopic classification with narrow band imaging for gastric precancerous and cancerous lesions / P. Pimentel-Nunes, M. Dinis-Ribeiro, J. B. Soares [et al.] // Endoscopy. - 2012. - No. 44. - P. 236-246.

13. Cho J. H. Clinical applicability of gastroscopy with narrow-band imaging for the diagnosis of Helicobacter pylori gastritis, precancerous gastric lesion, and neoplasia / J. H. Cho, S. R. Jeon, S. Y. Jin // World J. Clin. Cases. 2020. - Vol. 8 (14). - P. 2902-2916.

14. Narrow band imaging and serology in the assessment of premalignant gastric pathology / J. R. White, S. S. Sami, D. Reddiar [et al.] // Scandinavian Journal of Gastroenterology. - 2018. - Vol. 53 (12). - P. 1611-1618.

15. A new method of diagnosing gastric intestinal metaplasia: narrowbandimaging with magnifying endoscopy/ N. Uedo, R. Ishihara, H. Lishi [et al.] // Endoscopy. - 2006. - No. 38. - P. 819-824.

16. Graham D. Y. Diagnosis: gastric intestinal metaplasia - what to do next? / D. Y. Graham, M. Rugge, R. M. Genta // Curr. Opin. Gastroenterol. - 2019. - Vol. 35 (6). - P. 535-543. 


\section{REFERENCES}

1. Dinis-Ribeiro $M$, Areia $M$, de Vries AC, MarcosPinto R, Monteiro-Soares M, O'Connor A, et al. Management of precancerous conditions and lesions in the stomach (MAPS): guideline from the European Society of Gastrointestinal Endoscopy (ESGE), European Helicobacter Study Group (EHSG), European Society of Pathology (ESP), and the Sociedade Portuguesa de Endoscopia Digestiva (SPED). Endoscopy. 2012;44(1): 7494. DOI:10.1055/s-0031-1291491.

2. Pimentel-Nunes P, Libânio D, Marcos-Pinto R, Areia M, Leja M, Esposito G, et al. Management of epithelial precancerous conditions and lesions in the stomach (MAPS II): European Society of Gastrointestinal Endoscopy (ESGE), European Helicobacter and Microbiota Study Group (EHMSG), European Society of Pathology (ESP), and Sociedade Portuguesa de Endoscopia Digestiva (SPED) guideline update 2019. Endoscopy. 2019;51(4): 365-88. DOI: 10.1055/a-0859-1883.

3. Sugano K, Tack J, Kuipers EJ, Graham DY, ElOmar EM, Miura S, et al. Kyoto global consensus report on Helicobacter pylori gastritis. Gut. 2015;64(9): 1353-67. DOI: 10.1136/gutjnl-2015-309252.

4. Stepanov YuM, Simonova OV, Mosiichuk LM, Petishko OP. [Modern endoscopic criteria for stratification of patients with atrophic gastritis in the development of precancerous changes of the stomach]. Patholohiia. 2018;15(3): 346-53. DOI: 10.14739/2310-1237. 2018.3.151857. Ukrainian.

5. Rodriguez-Castro KI, Franceschi M, Miraglia C, Russo M, Nouvenne A, Leandro G, et al. Autoimmune diseases in autoimmune atrophic gastritis. Acta Biomed. 2018;89(8-S): 100-3. DOI: 10.23750/abm.v89i8-S.7919.

6. Cellini M, Santaguida MG, Virili C, Capriello S, Brusca N, Gargano L, et al. Hashimoto's Thyroiditis and Autoimmune Gastritis. Front Endocrinol (Lausanne). 2017;8: 92. DOI: 10.3389/fendo.2017.00092.

7. Kandemir EG, Yonem A, Narin Y. Gastric carcinoma and thyroid status. J Int Med Res. 2005;33(2): 222-7. DOI: $10.1177 / 147323000503300210$.

8. Venerito M, Radünz M, Reschke K, et al. Autoimmune gastritis in autoimmune thyroid disease. Alimentary Pharmacology \& Therapeutics. 2015;41(7): 686-93. DOI: 10.1111/apt.13097.
9. Stepanov YuM, Simonova OV, Mosiichuk LM. [Modern endoscopic technologies of precancerous stomach conditions diagnostics: problems and possibilities]. Hastroenterolohiia. 2017:51(1): 64-72. DOI: 10.22141/23082097.51.1.2017.97873. Ukrainian.

10. Comprehensive Atlas of High Resolution Endoscopy and Narrowband Imaging. Editor J. Cohen. Blackwell Publishing, 2009. Translation from English, edited by A.A. Budzinsky. Moscow: Logosphere; 2012. ISBN 9785-98657-028-0. Russian.

11. East JE, Vleugels JL, Roelandt P, Bhandari $P$, Bisschops R, Dekker E, et al. Advanced endoscopic imaging: European Society of Gastrointestinal Endoscopy (ESGE) Technology Review. Endoscopy. 2016;48(11): 1029-45. DOI: 10.1055/s-0042-118087.

12. Pimentel-Nunes $P$, Dinis-Ribeiro $M$, Soares JB, Marcos-Pinto R, Santos C, Rolanda C, et al. A multicenter validation of an endoscopic classification with narrow band imaging for gastric precancerous and cancerous lesions. Endoscopy. 2012;44(3): 236-46. DOI: 10.1055/s-00311291537.

13. Cho JH, Jeon SR, Jin SY. Clinical applicability of gastroscopy with narrow-band imaging for the diagnosis of Helicobacter pylori gastritis, precancerous gastric lesion, and neoplasia. World J Clin Cases. 2020;8(14): 2902-16. DOI:10.12998/wjcc.v8.i14.2902.

14. White JR, Sami SS, Reddiar D, Mannath J, OrtizFernández-Sordo J, Beg S, et al. Narrow band imaging and serology in the assessment of premalignant gastric pathology. Scandinavian Journal of gastroenterology, 2018;53(12): 1611-8. DOI: 10.1080/00365521.2018.1542455.

15. Uedo N, Ishihara R, Iishi $\mathrm{H}$, Yamamoto S, YamamotoS, Yamada $T$, et al. A new method of diagnosing gastric intestinal metaplasia: narrow-band imaging with magnifying endoscopy. Endoscopy. 2006 Aug;38(8): 819-24. DOI: $10.1055 / \mathrm{s}-2006-944632$.

16. Graham DY, Rugge M, Genta RM. Diagnosis: gastric intestinal metaplasia - what to do next? Curr Opin Gastroenterol. 2019;35(6): 535-43. DOI:10.1097/ MOG.0000000000000576. 